\title{
Marketing African and Oceanic Art at the High-end of the Global Art Market: The Case of Christie's and Sotheby's
}

\section{Tamara Schild}

\section{(2) OpenEdition \\ Journals}

Electronic version

URL: http://journals.openedition.org/anthrovision/4444

DOI: 10.4000/anthrovision.4444

ISSN: 2198-6754

Publisher

VANEASA - Visual Anthropology Network of European Association of Social Anthropologists

\section{Electronic reference}

Tamara Schild, « Marketing African and Oceanic Art at the High-end of the Global Art Market: The Case of Christie's and Sotheby's », Anthrovision [Online], Vol. 7.1 | 2019, Online since 11 March 2020,

connection on 12 November 2020. URL : http://journals.openedition.org/anthrovision/4444 ; DOI :

https://doi.org/10.4000/anthrovision.4444

This text was automatically generated on 12 November 2020.

(c) Anthrovision 


\title{
Marketing African and Oceanic Art at the High-end of the Global Art Market: The Case of Christie's and Sotheby's
}

\author{
Tamara Schild
}

\section{Introduction}

1 A recent report on the evolution of the African and Oceanic art market reveals the emergence over the past ten years of a high-end market (Thibault 2018: 49). It is dominated by the auction corporations Christie's and Sotheby's which are trading on the value of their brands and reputations while counting on their extensive client databases and powerful marketing machines. In 2018, the sales of African and Oceanic art by the two corporations totaled $€ 47,6$ million. ${ }^{1}$ These accounted for 62.4 percent of the global turnover during this year in monetary terms despite having sold only 10.5 percent of the combined total number of lots of African and Oceanic art offered at auction (Artkhade Report 2019: 10). These figures, together with an increase of many millions from all auction sales, indicate a strong high-end market.

2 To achieve their sales goals, the African and Oceanic art departments of Christie's and Sotheby's have adopted the same tactics the corporations have applied to all their departments. That is, an upper market strategy which mainly consists of four strategies: (1) Selling fewer objects at higher price points. For several years now, both corporations have focused on offering carefully selected pieces fresh to the market bolstered by distinguished provenance; (2) Securing and selling the most prestigious collections; ${ }^{2}$ (3) Deploying vast marketing strategies ${ }^{3}$ in print and digital media as well as managing exclusive events that promote rarity, prestige, exclusivity and trend; (4) Enticing modern and contemporary art collectors to the African and Oceanic art arena 
by capitalizing on the historical link between African and Oceanic art and European modernism (cf. Thibault 2018: 50).

This article will review and assess the development of Christie's and Sotheby's African and Oceanic art departments' marketing strategy over the past two decades. It is a well established and frequently-told story that during the first decades of the twentieth century, the aesthetic and the sacred aspects of African sculpture became important influences on European avant-garde artists such as Derain, Vlaminck, Picasso and Matisse. Stimulated by the stylized treatment of the human figure in African art, artists saw in it a solution to break with the canon of European realism. Along with famous dealers of the time such as Joseph Brummer or Paul Guillaume, they were forerunners of an aesthetic appreciation of African and Oceanic pieces that paved the way for the arts' reclassification in the art world. ${ }^{4}$ Between the Renaissance and first part of the nineteenth century, African and Oceanic artifacts had been collected and traded as curiosities. Later they were colonial trophies and ethnographic specimens. In the hands of avant-garde artists and their dealers, 'they became modernist icons worthy of aesthetic contemplation' (Biro 2015: 1). They became fine art.

Since the beginning of the twenty-first century, auction house specialists have used this well-known historical link between these European and African art forms to entice wealthy collectors from the lucrative modern and contemporary art markets to African and Oceanic art. Facing an aging client base, a new generation of auction house specialists put this historical link forward in the sales they organized. The departments started to schedule strategically their art of Africa and Oceania auctions and pre-sale viewings to coincide with their sales of modern and contemporary art. They were also scheduled to coincide with international art fairs in order to benefit from exposure to a global community of high-end collectors with eclectic tastes. As a result, collectors of modern and contemporary art entered the African and Oceanic art market.

5 In the first section of the article, I examine the profiles of two new players of the African and Oceanic art market - modern auction house specialists and new buyers. I further discuss the role they have each played in the promotion and reception of African and Oceanic art since the turn of the century. In the second part, I will present the results of a review of 180 sales catalogues produced by the auction houses between $1966^{5}$ and 2019. I will trace and discuss how specialists have used the engagement of European avant-garde artists with African and Oceanic art as a narrative (storytelling strategy) to enhance the value of objects and their main incentives to propagate the close relationship between both art forms. The marketing strategies directed towards cross-category collectors will be analyzed in the third part through a detailed analysis of Christie's series of thematic African and Oceanic art sales which take place every year in May in New York during $20^{\text {th }}$ Century Week and which are tailored to this specific type of buyers. Finally, I will consider the implications of Christie's and Sotheby's upper-market strategies on the reevaluation of aesthetic canons in the field of African and Oceanic art today.

6 The assertions I make are based on a quantitative and qualitative survey of 180 African and Oceanic art auction catalogues produced by the two corporations. The procedure I followed involved sorting all catalogues notes where the mention of the link of African and Oceanic art to modern and contemporary is made by date, by auction house (Christie's/Sotheby's) and by location (London/Paris/New York), and studying their discursive content. The study and my conclusions were supported by extensive 
fieldwork observations, reviews of advertisement, sale announcements and sales results, and interviews with key market players (auction house specialists and collectors).

\section{New Market Actors}

\section{A New Generation of Auction House Specialists}

7 In the first decade of this century Christie's and Sotheby's relied on a new generation of African and Oceanic art specialists. Their profiles differed from those of previous specialists such as William Fagg (1914-1992), former keeper of the department of Anthropology at the British Museum and founder of a dedicated Tribal Art department at Christie's. Fagg was trained in anthropology and museology and had done fieldwork in several regions of West Africa during the colonial period. Many of the new African and Oceanic art specialists have studied art history, philosophy or business. As a group they are well-versed in curating, marketing, and art criticism, and work in a different geopolitical and historical context than their predecessors. These specialists work with new technologies and online marketing as well as the changing patterns of global wealth and how it has reshaped the art industry and the art market landscape in general. They are also increasingly confronted with the problematic cultural legacy of colonialism in this collecting field and a changing view of European colonialism in Africa (cf. Sarr \& Savoy 2019). To these specialists, cultural productions of Africa and Oceania have the same artistic legitimacy as any other art form. Heinrich Schweizer, for instance, who was Sotheby's Head of African and Oceanic Art in New York from 2006 to 2015, studied art history and philosophy and holds a doctoral degree in Law. Son of a sculptor and a painter, he began collecting African art when he was ten years old. He says about his initial approach to non-European art:

'I always looked at African and Oceanic art from a universal perspective, which was how my parents brought me up. I never 'compartmentalized' between different categories of art or bought into how you must use different lingo when talking about Western art versus Indian art, say, or Antiquities or African and Oceanic art' (Schweizer 2012: n.p., italics by the author).

8 From 2001 to 2002, Schweizer was a freelance journalist covering the international market for African and Oceanic art. In 2006, Sotheby's appointed him as Head of the African and Oceanic Art department in New York. The press release that announced his appointment is very revealing as to the strategy discussed in the present paper. Indeed, Schweizer had already outlined the strategy his department was going to follow under his tenure:

'I'm very pleased to join Sotheby's New York which is an established presence in the field of African \& Oceanic art at a time when there are many new opportunities for growth. African \& Oceanic art influenced some of the greatest 20th century artists and increasingly holds crossover appeal from collectors in the modern and contemporary areas, particularly in New York where many of our most important auctions are held'. 6

Susan Kloman, Christie's International Head of Department, is also a key figure in the development of the marketing strategy being discussed. She received her master's degree in art history with a focus on modern art and art of Africa, Oceania and the Americas. Prior to joining Christie's in 2008, she served eight years as head of the New York Department of African and Oceanic art at Sotheby's and worked as an 
independent consultant. Her early research into the influence of non-European art on modern Western art continues to support her current professional activities. In introductory essays to sales catalogues and in promotional materials produced for Christie's, she often comments on this historical and conceptual link (see below). A hallmark of her tenure has been tightly curated (thematic) African and Oceanic art sales tailored specifically to cross-category collectors which take place in New York during Christie's $20^{\text {th }}$ Century Week alongside their sales of Impressionist, modern, post-WWII, and contemporary art.

Heinrich Schweizer and Susan Kloman have striven to position African and Oceanic art within what they consider to be a more inclusive occidental art history, a cause supported by many of their colleagues. Together with others, they have been highly influential in cultivating and advising the group of cross-category collectors and crosscategory buyers at Sotheby's and Christie's respectively. Indeed, auction house specialists have now taken on the role of advisors, sometimes bypassing private art dealers.

\section{The Production of the Cross-collectors}

11 Following the new marketing strategy, collectors of modern and contemporary art entered the African and Oceanic art market in large numbers around 2007, just as the art market was on the cusp of a boom. Entrepreneurs and individuals with significant financial means who focus on high-quality art with impeccable provenance from other departments of Christie's and Sotheby's were encouraged to join the African and Oceanic sales where masterpieces were still available at relatively low prices. 2006 had been a strong year for African and Oceanic art due to the success of the legendary Vérité sale at Enchères Rive Gauche in Paris that brought several new price records and totaled $€ 44$ million, and the opening of the Musée du Quai Branly, Paris. According to Schweizer, the sale of the Saul and Marsha Stanoff collection by Sotheby's New York in the following year marked a turning point in the art market:

'The following spring, we presented the Saul and Marcia Stanoff Collection together with a few masterpieces deaccessioned by the Albright-Knox Art Gallery in Buffalo. This auction broke all records and generated \$25 million - half the sum that the Vérité sale had totaled but with only one quarter of lots. That sale of May 2007 was the true turning point in the market, marking the beginning of a new era. The quality of the works on offer was so great that it attracted the interest of art collectors outside the African and Oceanic art field, who, for the first time, entered the market on a broad front. Our cultivation and continuous expansion of this collector group led to the reassessment of the top of the market in our category' (Schweizer 2012: n.p.).

12 However, it seems that not only the quality of the pieces but also the higher prices awakened the interest of exogenous buyers and collectors who might otherwise would never had thought of considering African and Oceanic art. The higher prices gave a sense of confidence and enticed them to come into the market (cf. Thibault 2015: 53).

Some seasoned collectors have looked askance at these new buyers. A long-time collector commented on the profile of the cross-collector: 'He is a guy who today buys an African mask and tomorrow he buys a Francis Bacon ... It is related to the field of paintings. He understands that an African mask goes well with a Picasso, so he buys it' (personal communication, 26 September 2016). 
This statement suggest that cross-category collectors have been motivated only by fashion and financial investment. ${ }^{7}$ Seasoned collectors further criticize the supposed lack of time these new buyers apply to studying African and Oceanic art, a collecting field they believe requires a strong intellectual commitment. Some dealers also disapprove of cross-collectors' buying habits, which are rather distinct: generally, they prefer to buy pieces whose quality will be certified and who are published, and thus prefer to purchase from auction houses. Indeed, according to Schweizer (2012), 'newer collectors often start out at auction because they appreciate the level of expertise, compliance standards and transparency of pricing' (Schweizer 2012: n.p.).

However, a brief look at the profile of two cross-category collectors, Javier Peres and Adam Lindemann, shows that it would be an over-simplification to think that they buy African and Oceanic art only for reasons of prestige and investment. A closer look produces a far more complex and subtle picture.

Javier Peres (born 1972, Cuba) perfectly represents a new generation of African art collectors with eclectic tastes. He is the founder of the cultural institution Peres Projects which currently operates an exhibition space located on Karl-Marx-Allee in Berlin. It promotes contemporary painting, conceptual art and sculptures. Since its founding in San Francisco in 2002, Peres Projects has represented contemporary artists including Joe Bradley, Bruce LaBruce, David Ostrowski, and Donna Huanca. In 2006, Peres, who built a reputation as a 'champion of cutting-edge artists' (O'Hagan 2018), was included in the Art Review Power 100 ranking of the most influential people in the contemporary art world. ${ }^{8}$ Javier Peres has collected African art for nearly two decades. He says about his interest in African art:

'I have been interested in African art since I was in my early teens. It was a combination of my interest in modernism and early $20^{\text {th }}$ century artists combined with my interest in ancient civilizations. By the time I was in my mid to late teens my interest had also reached the contemporary art field and particularly Basquiat and this made the interest in classic African art even stronger' (personal communication, 26 September 2019).

7 First attracted by the formal beauty of carvings from Côte d'Ivoire and neighbouring countries, his taste evolved under the influence of advisors such as Bruno Claessens, European Head of Christie's African and Oceanic Art department. This has led to a more experimental and bold collection of sculptures from Nigeria, Cameroon, Gabon and the Democratic Republic of Congo (Peres 2016: 122,124).

8 In 2014 and 2016, Peres organized exhibitions in his Berlin gallery in which he juxtaposed African art from his own collection with contemporary art in a not entirely new curatorial gesture that 'removes premodern African objects from their original context in order to present them purely as art objects, using the same modes of presentation typical in contemporary art' (Peres in Buffestein 2016: n.p.).

For Adam Lindemann, who has collected art for about twenty years, African and Oceanic art was an introduction to art collecting in general. Coming from a wealthy family, he discovered this art as a student at Yale Law School through his encounter with the Belgian art dealer, Bernard de Grunne, son of the eminent African and Oceanic art collector Baudoin de Grunne (Dennison 2010: 32). Today Lindemann is a private investor and owner of the gallery Venus Over Manhattan, which opened in New York in 2012. In 2016, Lindemann organized an exhibition entitled Fétiche at his New York gallery, which assembled some thirty works of contemporary occidental art with 
ancient African and Oceanic works. In a foreword to the catalogue of the seventeenth edition of Parcours de Mondes (2018) whose honorary president he was, he said that he 'always loved juxtaposing contemporary Western art with historic African and Oceanic works as a means to examine the literal power that art objects confer' and that he is interested in the 'emotionally charged tension tribal art creates in contemporary contexts' (Parcours de Mondes 2018: n.p.). In 2017, Lindemann was the focus of attention as consignor of Jean-Michel Basquiat's painting Untitled (1982) which sold at Christie's for US\$57.3 million to Japanese billionaire Yusaku Maezawa. Before selling it, he bought an uli figurine from Papua New Guinea, the cover lot at Sotheby's African and Oceanic and Pre-Columbian art sale, for US $\$ 4,7$ million (Pogrebin 2016: n.p.).

These cross-collectors represent clear differences to traditional, specialized collectors, which Schweizer summarizes as follows:

'Here we are talking about collectors with a universal perspective on art. The number of such collectors has always been much smaller than the number of collectors of just African and Oceanic objects which can be of either artistic or ethnographic merit. A lot of material that might excite a traditional specialized collector of African Art does not have the same effect on these collectors to whom African and Oceanic Art is only one of several collecting interests. The latter spend a lot of time looking at and thinking about art in general. They often have extremely refined tastes, shaped by different art fields and eras. And they know exactly what they want' (Schweizer 2012: n.p., italic by the author).

Cross-category collectors show a clear focus on the objects and their aesthetics, which can, on occasion, lead to an ahistorical perspective. Lindemann, for example, has a deliberately Eurocentric perspective, and views African and Oceanic objects as valuable aesthetically regardless of their uses and meanings in the societies that produced them:

'African and Oceanic works were created in mystical or religious contexts, though in most instances their exact functions remain unknown. Though this is tragic from a human perspective, it has freed these objects to be viewed and appreciated from a more aesthetic perspective. Early collectors historically stripped them of their native contexts, and often of their original patina, instead focusing on their aesthetic "otherness". Today, these objects exist as much more than curios or spoils of colonialism. They cannot be reduced to rare and exotic souvenirs of cultures forever disrupted by the advance of Western civilization. They have influenced our own art history and, in my mind, remain some of the most compelling works ever created' (Lindemann 2018: n.p.).

In this quote, Lindemann establishes an intellectual genealogy to the collectors of the early twentieth century. Indeed, it is interesting to note that today's cross-category collectors have similar profiles and approaches to the amateurs of 'l'art nègre.' They were mainly artists, intellectuals, bourgeois and art dealers and they associated African and Oceanic art with other forms of art (cf. Amrouche 1990: 127; Biro 2018).

\section{The Narrative Enhancement of African and Oceanic Art in Auction Catalogues}

Sotheby's, followed by Christie's, cultivated the cross-collector group as seen in the changes of their sales catalogues. My survey of 180 catalogues produced between 1966 and 2019 by these auction houses revealed that the engagement of European avantgarde artists with African and Oceanic art began to be used as a storytelling strategy to enhance the value of objects only relatively recently - since the beginning of the 
twenty-first century. The precise timeline of how this narrative has since been fleshed out is beyond the scope of the discussion. Therefore, I shall limit myself to sketching the development of the narrative in broad strokes and to showing how it is related to other changes in catalogue production and especially to provenance research. I will also list the three most common ways used in auction catalogues to link African and Oceanic art to modern art. Finally, I will comment briefly on the main incentives specialists had to propagate the close relationship between these art forms.

Until 1990, auction house specialists seemed to get along without references to European modernism in the marketing of pieces they sold. The names of early avantgarde artists appeared in the provenance list of the otherwise very dry catalogue notes only in the case where actual ownership was verifiable, and without any accompanying narrative. It may be noted in passing that this narrative is absent from sales catalogues in 1984, the year of the ground-breaking exhibition Primitivism in 20th Century Art: Affinity of the Tribal and the Modern (Museum of Modern Art, New York). Its curators had juxtaposed African, Oceanic and Native American Indian art with artworks of modern Western artists, hypothesizing affinities between them. This was a curatorial decision that had a great impact on the reception of African and Oceanic art in the United States and Europe.

During the 1990s, the African and Oceanic departments of Christie's and Sotheby's experienced increasing professionalization and academization. They introduced significant changes in catalogue production (Satov 1997; Geismar 2001). The sales catalogues became more academic: 'Footnotes, literary references, exhibitions, art historical analysis and ethnographic detail are examples of textual components which [became] increasingly frequent' (Satov 1997: 226).

26 Towards the end of the 1990s, catalogues progressively adopted a fine art aesthetic. Important pieces were published with several full-page colour photographs from different angles and close-ups to visually demonstrate rarity and quality (Geismar 2001: 35). Haidy Geismar (2001), who studied their designs at the turn of the twenty-first century, notes: 'In these catalogues we are given a striking insight into the ways in which academic knowledge, photographic techniques, visual 'aesthetic' criteria, historicity, and provenance are used in the construction of market values' Geismar 2001: 36).

27 Auction houses introduced standards of Western art history into their African and Oceanic art catalogue presentations and started to use terms borrowed from the fine art market. Massive research efforts were deployed to identify individual artists, their workshops and regional styles. Similarly, great effort was put into tracking the successive owners of the pieces sold. De facto, the increasing and finally systematic use of the narrative of Western artists' engagement with African art, was intimately connected with provenance research. Information gained through research helped flesh out the narrative in catalogue notes. This is especially apparent in Sotheby's catalogues and for sales taking place in New York.

If auction houses were to sell African and Oceanic art as fine art in an increasingly sophisticated marketplace, they would first have to change how it was perceived. They adopted several strategies for this purpose: they stopped marketing with the phrase 'tribal art' and instead promoted the more neutral notion 'African and Oceanic art' (cf. Thibault 2015: 54). By 2007 this was a consistent practice (Schweizer 2012: n.p.). The same year, Sotheby's, later followed by Christie's, introduced another important 
change in its catalogue design. For decades, auction houses had represented African and Oceanic sculptures on black backgrounds and under dramatic lighting. Freeing themselves from this exoticizing photographic technique, they stopped using a black background and adopted the white background commonly used for modern and contemporary art (Schweizer 2012: n.p.). Schweizer comments about the change at Sotheby's:

'We launched this new look for the first time in 2007 starting with the Stanoff sale. It was quite interesting to hear the reactions. The traditional collectors of African Art all said ' $\mathrm{hmm}$, this looks strange but not bad'. But when I talked to other colleagues at Sotheby's across other departments, they all said this looks really sexy. Most importantly, the fine art collectors who entered the market in 2007 responded positively' (Schweizer 2012: n.p., italics by the author).

Showing how this homogenization of the catalogue design was part of a larger marketing strategy directed towards cross-category collectors, he adds:

'It seems like such a minor thing but when you think of it: now, as you open a book or catalogue for Old Master Paintings, Greek and Roman sculpture, Contemporary Art and African Art - it all has the same look and you don't have the feeling anymore that you are walking into the "dark-forest-of-tribalism". And if you are a collector new to this field, you want to be able to relate to it and not be repelled by a look you are not familiar with' (Schweizer 2012: n.p., italics by the author).

It also became fashionable for auction houses to combine African and Oceanic art with modern and/or contemporary art. Specialists use three common ways to do so in auction catalogues: if a piece has been verifiably studied by a seminal modern artist and has influenced his or her oeuvre, comparisons have an art-historical background and represent significant provenance research. However, only a few artworks fit this category. An example is a Bamana seated female figurine from the private collection of Henri Matisse sold by Sotheby's in May 2012. Matisse depicted it in the background of his painting Les Trois Sceurs à la Sculpture Africaine (1917; Three Sisters with an African Sculpture), which is now in the collection of the Barnes Foundation in Philadelphia. The second reason to compare non-European and modern art is for their conceptual or aesthetic affinity: objects whose type influenced the European modernist movement but lacking verifiable proof of having belonged to an avant-garde artist. In this case, specialists often refer to a comparable piece owned by a renowned artist such as Picasso to elucidate in the catalogue note the cultural and historical context of the discovery of African and Oceanic art by modernist artists. Comparisons of this kind fall into the field of art criticism and connoisseurship. Therefore, when it comes to justifying high prices, auction houses pay scholars to discuss conceptual affinities or the significance of a non-European artwork within the context of occidental art history. In other cases, specialists undertake to comment on the conceptual and aesthetic affinities: Regarding a Fijian neck rest, for instance, Sotheby's auction catalogue of 11. November 2005 highlights the 'uncanny effect of animation which would have appealed deeply to the European founders of the Surrealist and Dada movements' (Sotheby's 2005: 26). In relation to a Mongo shield from the Democratic Republic of Congo Sotheby's sales catalogue of 5 December, 2007 emphasizes the 'abstract composition ... that is reminiscent of the pictorial language developed by Piet Mondrian at the beginning of the 1920s' (Sotheby's 2007: 130, personal translation). ${ }^{9}$ However, this strategy hides the risk of purely formalistic comparisons. Indeed, this is a third type of comparison found in auction catalogues: in the last few years, the juxtaposition of works that contain mere similarities of forms has multiplied and some of the claimed 
similarities appear farfetched. This problem is reflected in the derisive and annoyed reactions of some collectors (field notes, 16 May, 2018). This occurs in instances where they believe juxtapositions of African or Oceanic art forms with modern and contemporary art have been misrepresented to pressure potential buyers.

What were the main incentives for specialists to propagate the close relationship between African and Oceanic and modern art from the mid-2000s? The intention was to reach new groups of buyers, to legitimize quality by demonstrating that objects passed vetting by avant-garde artists, and ultimately to increase prices. The growing number of scholarly articles and catalogue notes on the historical link of African and Oceanic art and European modernism from 2007 to the present can be interpreted as an attempt to make African and Oceanic art familiar to a new group of collectors who came to it through their interest in modern or contemporary art. For these non-specialized audiences, the narrative of modernism seems to be an easy entry point, more intuitive and engaging than the traditional ethnological approach. Auction house specialists have striven to offer pieces to cross-category collectors that relate to what they were already looking at and to market African and Oceanic art in a way that it appears to facilitate the understanding of art they were already collecting. Christie's series of thematic African and Oceanic art sales that I subsequently discuss could be viewed as the culmination of this marketing strategy.

However, the need to rehabilitate the image of African and Oceanic art from its association with colonialism and illicit traffic of cultural goods in a post-colonial society, might be a second reason for specialists to favor this less controversial approach. As Geismar (2001) recalls: 'The tribal arts market has always been problematically internationalist, from the mass exportation of ethnographica during the colonial period ... [to] the theft of cultural property, and repatriation' (Geismar 2001: 32). Whereas the discovery of African art by seminal modern artists and the European art circles appears as being based in a recognition and valorization of nonEuropean cultural productions and cultures.

\section{Christie's Series of Thematic African and Oceanic Art Sales}

In its challenge to follow the lead of its rival Sotheby's, Christie's reacted in 2016 with tightly curated, thematic sales tailored to cross-category collectors coming from modern and contemporary art. They take place every May in New York during the corporation's $20^{\text {th }}$ Century Week alongside the auctions of Impressionist, modern, postWWII, and contemporary art. With Evolution of Form..$^{10}$ African and Oceanic Art at the Genesis of Modernism (Christie's New York, 12 May, 2016), Susan Kloman introduced what was then advertised by Christie's as a 'revolutionary' thematic sale. Kloman (2016) considered it an 'ode to the landmark exhibition curated by William Rubin at New York's Museum of Modern Art in 1984 - 'Primitivism' in $20^{\text {th }}$ Century Art' (Kloman 2016: 9). In a similar vein as the 1984 exhibition, Kloman juxtaposed African and Oceanic artworks with modern art in the sales catalogue to 'stimulate an aesthetic dialogue and highlight visual affinities' (Kloman 2016: 9). 

of the modern art' (Kloman 2016: 9). It profiled four works from Côte d'Ivoire, one Fang reliquary figurine from Gabon and two statues from the Democratic Republic of the Congo. These are the types of artworks and cultural areas that are the most sought after and highly priced (cf. Artkhade report 2019: 10), following an art canon which was established in the first decades of the twentieth century. Each lot in the highly elaborated sales catalogue was accompanied by a well-researched dossier containing an ethnographic and art historical discussion of the art object as well as detailed information on its provenance, exhibition histories and literary references. Regarding the estimates, they left no doubt as to the intended audience: nine out of eleven lots had a six-figure estimate and two a seven-figure estimate. The sale was a big success: Seven out of eleven lots sold for a total of US $\$ 5,039,000$. Kloman described all successful bidders as cross-over collectors, two clients making their first ever purchases in the field of African and Oceanic art (in Crichton-Miller 2016). 2017) celebrated 'the diversity of form and innovation of African artistry'. ${ }^{11}$ According to Susan Kloman (2017), the sale 'aspire[d] to reveal [the] universal qualities [of the masterpieces] and demonstrate their rightful place on the great world stage of art throughout time and space' (Kloman 2017: 8). She introduced the catalogue with a rather philosophical text on the meanings that African cultural creations hold for their makers, the metaphysical concepts conveyed in African art, and the human urge to create art. Rather than building the value of African art in relation to modernism, the second sale built a link to various types of classical art. The aim was to present African and Oceanic cultural productions as world art. ${ }^{12}$ The overall argument was that African art can be appreciated through an aesthetic that has both timeless and universal applications. A Dogon maternity figurine from Mali was contextualized in a timeline companion that presented the genesis of the maternal image from the Venus of Willendorf to Raphael's Madonna of the Goldfinch (1506) to Henry Moore's Mother and Child with Apple (1956), whereas a Baule mask from Côte d'Ivoire was juxtaposed with the Head of an Amarna Princess (Egypt, eighteenth Dynasty, Amarna Period). The strategy was successful insofar as eight out of twelve lots sold for a total of US $\$ 3,953,500$.

The third of Christie's series of thematic sales, Origins. Masterworks of African and Oceanic Art (Christie's New York, 17 May 2018), went a step further, and brought a group of 
selected artworks that markedly diverged from the art canons of the beginning of the twentieth century. The sale comprised more pieces from Cameroon and Nigeria than the two previous ones. Regarding pieces from Côte d'Ivoire or Congo, the examples were deliberately selected for their relatively atypical aesthetic:

'The hallmark of this special selection of thirteen magical works of art is its valorization of major works of art that fall outside the canon. Anti-classical. The twentieth century discovered and established classical African art, the $21^{\text {st }}$ makes us look further, at art that was not yet accessible to early $20^{\text {th }}$ century taste-makers, such as Charles Ratton and Paul Guillaume ... The works of art are selected for their pure creativity ... The Dan mask (lot 6) is an anti-aesthetic statement. Dan people highly value beauty, and their best masks are based upon symmetry. In its asymmetry, the mask is deemed wild. It is undomesticated ... With Origins, we are at the beginning of a new way to approach African and Oceanic art ... Origins is meant to defy those looking with Western eyes. Look at them from all angles. Upside down. There is no vetting by the European Avant-Garde. This is the Wild West. These are the rock stars of the art world stage. Never mind the bollocks, here's Origins.' (Kloman 2018: 6,7; italics added)

We can well consider that this selection of artworks and the way they were promoted would attract young and bold contemporary art collectors. Kloman's vocabulary supports such a view. Even so, this intentionality to give African and Oceanic art a more fashionable and trendy appeal was less successful, as only six out of thirteen lots sold for a total of US $\$ 1,754,250$.

In 2018, Christie's May sale Art of Africa. Masterworks was presented as 'a celebration of female strength, fertility, and beauty' and offered 'works of art that showcase the powerful influence of women in 19th century African culture'. ${ }^{13}$ The auction achieved a total of US $\$ 4,996,250$. The highlight of the sale was a Kifwebe mask (Democratic Republic of the Congo) which realized US $\$ 4,215,000$ setting a new world record for this type of object.

41 The format of these Christie's New York sales is revealing, each is curated around a topic that is introduced in the catalogue by an essay of Kloman. This latter one takes the form of a manifesto which intends to shape the opinion of potential collectors. The narrative progression from modern art (2016) to classic art (2017) to anti-classic art (2018) thus reveals the objective to widen the field of potential clients.

Christie's New York May sales also reveal the recent evolution of the auction market in general: As we have seen, the auction houses' upper-market strategy in recent years has been to sell fewer, carefully selected pieces with distinguished provenance that are fresh on the market and to concentrate all research and marketing efforts on those. The auction houses' African and Oceanic art departments have thereby intentionally produced and promoted what they have termed 'the universal masterpiece:'

'I think that the art market in general in the $21^{\text {st }}$ century is becoming less compartmentalized by regions or categories of artworks. There is one category that everybody wants: the universal masterpiece, the artwork that defies categorization and transcends regional styles and eras' (Schweizer 2012: n.p.).

Indeed, Sidney Kasfir (1984) used the term 'masterpiece syndrome' to describe how collectors and publishers favour certain works of African art by stating that 'pieces of exceptionally high quality and technical excellence are obviously preferred to mediocre works which may be far more widespread and representative of the culture' (Kasfir 1984: 184). This is even truer today for auction houses like Christie's and Sotheby's who operate at the high end of the market. 
A promotional video produced by Sotheby's for the sale of a major collection of African art in New York in $2017^{14}$ gives striking insight into the corporation's process of creating and promoting universal masterpieces.

This media file cannot be displayed. Please refer to the online document http:// journals.openedition.org/anthrovision/4444

Video: https://www.youtube.com/watch?v=nQ6i_ENjpfw

In this context, another marketing strategy developed by auction houses to increase both the perceived and the actual market value of certain unattributed African and Oceanic objects is the creation of artificial names. Specialists use two main strategies to create provisional names. The first is the identification of an artist's hand such as 'The Buli Master' (name based on location) or 'The master of the Cascade Coiffure' (name based on recurring formal or stylistic characteristics), and the second, a more recent and more criticized practice that consists in labelling (branding) certain objects using the names of the most renowned Western collectors to which they belonged ('The Rasmussen-de Havenon Dogon mask,' or 'The Coray-Kerchache Kota-Ndassa Reliquary Figure').

\section{Conclusion: Defining masterpieces, defying canons?}

47 From the series of Christie's May sales, which, as we said, is telling of the recent market evolution, I would like to propose, by way of conclusion and as a prospect for future research, some thoughts concerning the role of auction houses on the reevaluation of canons in the field of African and Oceanic art.

8 At the end of the 1990s, when Murray Satov interviewed Christie's and Sotheby's African and Oceanic art specialists about their influence on setting trends and fashions in the field, the latter rather downplayed their role in this regard. They stated that their power to determine taste or generate a fashion was limited and they viewed museums and art galleries as far more influential (Satov 1997: 235). However, the foregoing discussion of recent developments in the auction market suggests reconsidering the question. The fact that Christie's and Sotheby's are constantly expanding and intensifying their range of activities (mounting exhibitions, advising clients, staging art-oriented events, etc.) and therefore engage in the practices of other cultural institutions further suggests that their influence is likely to grow.

9 My review of Christie's May auctions supports the idea that in their quest for new buyers from the modern and contemporary art worlds, auction houses are consolidating aesthetic canons of avant-garde artists and French taste-makers of the early twentieth century into the marketing of African and Oceanic art. Their high-end strategy has led them to produce masterpieces, chosen primarily to be appreciated by collectors who are particularly sensitive to a modernist aesthetic and looking for iconic pieces. ${ }^{15}$ The characteristics of these pieces are consistent with the aesthetic canons inherited from the European avant-garde, which Christie's and Sotheby's are subsequently consolidating.

However, as we have also seen, the constant need of the art market to innovate and attract new audiences, challenges Christie's and Sotheby's to broaden the scope of new 
ideas to further the appreciation of African and Oceanic art, rather than building its value exclusively on its relation to European modernism. The question, then, is whether Christie's and Sotheby's African and Oceanic art departments will reinvent themselves in the context of a changing view of European colonialism and expand their marketing of African and Oceanic art in ways that consider and reflect these changes?

\section{BIBLIOGRAPHY}

Books and articles

Amrouche, Pierre. 1990. De L'art nègre à l'art africain: un point de vue commercial. Arts d'Afrique Noire, Colloque AAN: 127-129.

Artkhade. 2019. Report 2019, Arts from Africa, Asia, Oceania and the Americas. Available online: https://www.artkhade.com/2/fr/publication (accessed 20 September, 2019)

Bellingham, David. 2017. 'On Cross Collecting, or Cross-Over Buying. Old and New Cross-Collecting Practices'. London and New York: Sotheby's Institute of Art. April 4, 2017. https:// www.sothebysinstitute.com/news-and-events/news/cross-collecting/ (accessed 23 February, 2019).

Biro, Yaëlle. 2015. African Arts Between Curios, Antiquities, and Avant-Garde at the Maison Brummer, Paris (1908-1914). Journal of Art Historiography 12: 1-15.

Biro, Yaëlle. 2018. Fabriquer le regard. Marchands, réseaux et objets d'art africains à l'aube du XXe siècle. Dijon: Les Presses du réel.

Buffestein, Alyssa. 2016. 'What Do Ancient Artifacts and Contemporary Paintings Have in Common?'. Brooklyn, NY et al.: VICE media group. 25 June 2016. https://www.vice.com/en_uk/article/ xy433w/peres-projects-african-sculptures-paired-with-contemporary-western-art (accessed 23 February, 2019).

Christie's. 2017. Timeless: Masterworks of African Art. Press release May 19, 2017 https:// www.christies.com/presscenter/pdf/8685/REL_African\%20\&\%200ceanic_May2017_8685_1.pdf (accessed 10 January, 2020).

Christie's. 2018. Art of Africa Masterworks. Press release May 2, 2018 https://www.christies.com/ about-us/press-archive/details?PressReleaseID=9369\&lid=1\&mob-is-app=false (accessed 10 January, 2020).

Clifford, James. 1988. The Predicament of Culture: Twentieth-Century Ethnography, Literature, and Art. Cambridge: Harvard University Press.

Crichton-Miller, Emma. 2016. Tribal Art on Its Own Terms. Apollo The International Art Magazine August 10, 2016. n.p. https://www.apollo-magazine.com/tribal-art-on-its-own-terms/ (accessed 23 February, 2019).

Dennison, Matthew. 2010. Living with African Art. Sotheby's at Auction May-June, 2010 Available online: http://www.adamlindemann.com/wp/wp-content/uploads/2011/07/Sothebys-atAuction.pdf (accessed 23 February, 2019). 
Errington, Shelly. 1994. What Became Authentic Primitive Art? Cultural Anthropology 9(2): 201-226.

Errington, Shelly. 1998. The Death of Authentic Art and Other Tales of Progress. Berkeley et al: University of California Press.

Fabian, Johannes. 2014 (1983). Time and the Other: How Anthropology Makes Its Object, $3^{\text {rd }}$ Edition. New York: Columbia University Press.

Geismar, Haidy. 2001. What's in a Price? An Ethnography of Tribal Art at Auction. Journal of Material Culture 6(1): 25-47.

Kasfir, Sidney L., 1984. One Tribe. One Style? Paradigms in the Historiography of African Art. History in Africa 11: 163-193.

Kloman, Susan. 2016. Prologue: The Discovery. In Evolution of Form. African and Oceanic Art at the Genesis of Modernism. Auction catalogue., 12 May 2016, Christie's (New York, 2016). Pp. 9.

Kloman, Susan. 2017. Timeless. An introduction. In Timeless. Masterworks of African Art. Auction catalogue. 19 May 2017, Christie's (New York, 2017). Pp. 8.

Kloman, Susan. 2018. Origins: Or Where the Wild Things Are. In Origins. Masterworks of African and Oceanic Art. New York, 17 May 2018, Christie's (New York, 2018). Pp. 6,7.

Lindemann, Adam. 2018. Foreword by the Honorary President of the Seventh Parcours des Mondes. Catalogue Parcours des Mondes 2018: n.p.

Monroe, John Warne. 2019. Metropolitan Fetish. African Sculpture and the Imperial French Invention of Primitive Art. Ithaca: Cornell University Press.

O'Hagan, Sean. 2018. Inside the Home of Gallerist Javier Peres, Champion of Cutting-Edge Artists. W magazine. June 13, 2018 https://www.wmagazine.com/story/gallerist-javier-peres-berlin-home (accessed 23 February, 2019).

Peres, Javier. 2016. \#Obsessed: Javier Peres and African Art. Interview by Jonathan Fogel. Tribal Art Magazine 79 (April): 120-127. http://www.tribalartmagazine.com/assets/pdf/ people_218_fr.pdf (accessed 14 January, 2020).

Pogrebin, Robin. 2016. A Collector's-Eye View of the Auctions. New York Times May 15, 2016. https://www.nytimes.com/2016/05/16/arts/design/a-collectors-eye-view-of-the-auctions.html (accessed 23 February, 2019).

Price, Sally. 2001 (1989). Primitive Art in Civilized Place, $2^{\text {nd }}$ Edition. Chicago: University of Chicago Press.

Sarr, Felwine and Bénédicte Savoy. 2018. Rapport sur la restitution du patrimoine culturel africain. Vers une nouvelle étique relationnelle. Paris: Philippe Rey/Seuil.

Satov, Murray. 1997. Catalogues, Collectors, Curators: The Tribal Art Market and Anthropology. In Contesting Art. Art, Politics and Identity in the Modern World. Jeremy MacClancy, ed. Pp. 215-239. Oxford: Berg Publishers.

Schweizer, Heinrich. 2012. Interview with: "Heinrich Schweizer". Sotheby's Senior Vice President, Department Head African \& Oceanic Art NY'. Interview by Michael Aulisio. Half Moon Bay, CA: Tribalmania Gallery. https://www.tribalmania.com/interviewheinrich.html (accessed 23 February, 2019).

Sotheby's. 2007. Arts d'Afrique et d'Océanie. Auction catalogue. Paris, 5 December 2007.

Thibault, Clément. 2015. The Tribal Art Market 2000-2015. Paris: Artkhade, Art Media Agency and Art Analytics. 
Thibault, Clément. 2018. Art Tribal 2017. Art Media Agency Newsletter 307 (11 September): 49-57.

Films

Christie's. 2016a. 'African, Oceanic \& Tribal Influences on Contemporary Art'. Christie's.com. https:// www.christies.com/features/African-and-Oceanic-connections-to-contemporaryart-7248-3.aspx?sc_lang=en\#FID-7248, (accessed 18 April, 2016).

Christie's. 2016b. 'Modernism and the influence of African \& Oceanic Art'. Christie's.com. https:// www.christies.com/features/Tracing-the-influence-of-African-and-Oceanic-art-7349-3.aspx (accessed 10 May, 2016).

Sotheby's. 2017. Icons of African Art. Sotheby's, 23 October 2017 YouTube. https:// www.youtube.com/watch?v=nQ6i_ENjpfw (accessed 23 October, 2017).

\section{NOTES}

1. Nevertheless, the African and Oceanic art market remains a niche market within the industry. In 2014, a record-setting year for the African and Oceanic art market, the segment accounted for only 0.68 percent of the total auction sales volume of art (Thibault 2015: 17).

2. That way, between 2017 and 2019, Christie's managed to sell the collections of Jean-Pierre and Angela Laprugne ( $€ 2$ million), Jeannine and Claude Verité ( $€ 16,7$ million), Liliane and Michel Durand-Dessert ( $€ 6,1$ million) and Adolphe Stoclet ( $€ 1,3$ million) while Sotheby's auctioned off the collections of Edwin and Cherie Silver (US\$7,1 million), Howard \& Saretta Barnet (US $\$ 8,3$ million), Elisabeth Pryce (US\$994 thousand), Harry A. Franklin (US\$1,9 million) and Marceau Rivière (€11,48 million).

3. Marketing expenses for a various-owner sale can be estimated to be in the lower five-digit range.

4. There is an abundance of literature about the French and North American reception of African art and its development as a Western aesthetic category (Biro 2018, Monroe 2019, to mention only the most recent ones).

5. The year of the sale of Helena Rubinstein's collection at Sotheby's Parke-Bernet in New York.

6. See https://sothebys.gcs-web.com/static-files/f031853a-d2fb-4ada-ba2b-4774e0edf47c (accessed 24 September 2019)

7. An argument that is reinforced by David Bellingham (2017), Program Director for the Master's Degree in Art Business at Sotheby's Institute of Art, according to whom 'contemporary crosscollecting reflects the increasing crossovers between the financial world and the art market, with the creation of a mixed art collection mirroring the hedge fund portfolio: when one sector is underperforming, others tend to excel' (Bellingham 2017: n.p.).

8. See https://artreview.com/power_100/2006/ (accessed 24 September 2019)

9. 'La composition abstraite ornant ce bouclier n'est pas sans rappeler le langage pictural développé par Piet Mondrian au début des années 1920' (Sotheby's, Arts d'Afrique et d'Océanie, Paris, 5 December, 2007, auction catalogue, lot 89, p. 130).

10. The titles of the auctions (e.g. Timeless, Origins) and the rhetoric of the video clips (see below) would deserve some critical analysis with regard to what notions of African and Oceanic art are transmitted. Since this goes beyond the scope of the article, I wish to refer readers to the works of Johannes Fabian (2014[1983]), Sidney L. Kasfir (1984), James Clifford (1988), Sally Price (2001[1989]) and Shelly Errington (1998) who have questioned this kind of rhetoric very critically.

11. See Christie's 2017 https://www.christies.com/presscenter/pdf/8685/ REL_African\%20\&\%200ceanic_May2017_8685_1.pdf (accessed 23 February 2019). 
12. Auction houses use the term 'world art' in its old meaning where it designates all art that is not treated in occidental art history and has a universalistic underpinning. Christie's World Art group comprises the departments African \& Oceanic Art, Ancient Art \& Antiquities, Indian, Himalayan \& Southeast Asian Art, South Asian Modern + Contemporary Art.

13. See https://www.christies.com/about-us/press-archive/details? PressReleaseID=9369\&lid=1\&mob-is-app=false (accessed 24 September 2019)

14. Sotheby's, The Collection of Edwin and Cherie Silver, New York, 13 November, 2017. At the time Sotheby's was losing its leading position in this segment which justified a big marketing campaign.

15. With the humorous rhetorical question 'Formal Qualities, or Does it Look Modern?' Shelly Errington (1994: 217, 1998: 92) already emphasized that a main criterion for canonical African and Oceanic art is its closeness to European modernism: 'The basic core of objects that define the prototype consists of objects that actually did influence, or look as if they could have influences, the likes of Picasso and Maurice de Vlaminck' (1994: 219, 1998: 97).

\section{ABSTRACTS}

This article examines both the development and implications of a sales strategy deployed by Christie's and Sotheby's from the mid-2000s to increase their market share and the prices of African and Oceanic art. The strategy was designed to entice affluent modern and contemporary art collectors with eclectic tastes to African and Oceanic art and to develop cross-category collecting between the two art market segments. This was achieved by capitalizing on the historical links between these art forms and by timing the African and Oceanic art auctions and pre-sale viewings to coincide with sales of modern and contemporary art. A survey of sales catalogues produced by the two corporations between 1966 and 2019 documents how specialists have used the engagement of avant-garde artists with non-European art forms as a storytelling device to enhance the value of African and Oceanic artworks. I argue that in the African and Oceanic art departments' quest for buyers of modern and contemporary art, auction houses are consolidating aesthetic canons established by avant-garde artists and French tastemakers of the early twentieth century with their current marketing of African and Oceanic art.

Cet article étudie le développement et les implications des stratégies de vente déployées par Christie's and Sotheby's à partir du milieu des années 2000 afin d'augmenter les prix et les ventes d'art africain et d'art océanien en attirant des collectionneurs d'art moderne et d'art contemporain aux goûts éclectiques. Cet objectif fut atteint en mettant en avant les liens historiques qu'entretiennent ces arts et en faisant coïncider les calendriers des ventes des départements respectifs. La recension des catalogues de ventes produits par Christie's et Sotheby's entre 1966 et 2019 montre comment les spécialistes ont utilisé l'intérêt des artistes d'avant-garde pour l'art africain et océanien dans une stratégie de mise en valeur narrative des objets. Je développe l'argument que par leur volonté d'attirer des acheteurs d'art moderne et contemporain, et par leurs stratégies de commercialisation actuelles, les départements d'art d'Afrique et d'Océanie de Christie's et Sotheby's consolident les canons artistiques établis par les artistes d'avant-garde européens et par leurs marchands au début du XXème siècle. 
Este artículo examina el desarrollo y las implicaciones de una estrategia de ventas implementada por las empresas de subastas Christie's y Sotheby's a partir de mediados de la década de 2000 para aumentar sus ventas y precios del arte africano y oceánico. La intensión fue de atraer a coleccionistas adinerados de arte moderno y contemporáneo con gustos eclécticos para reforzar lo que llaman el " cross-collecting » entre estos campos artísticos. Este objetivo se logró destacando el vínculo histórico del arte de Africa y Oceanía con las vanguardias europeas y alineando los calendarios de los respectivos departamentos. Una encuesta de catálogos de ventas producidos por Christie's y Sotheby's entre 1966 y 2019 documenta cómo los especialistas han utilizado el interés de los artistas de vanguardia por el arte africano y oceánico como narrativa para aumentar el valor de los objetos. Sostengo que en su búsqueda de nuevos clientes en el campo del arte moderno y contemporáneo las casas de subastas están consolidando cánones estéticos establecidos por los artistas de vanguardia y por los forjadores del gusto francés de principios del siglo XX.

\section{INDEX}

Mots-clés: Art africain, art océanien, Avant-garde européenne, marché des ventes aux enchères, stratégies marketing, catalogues de ventes aux enchères, cross-collectors, Christie's, Sotheby's

Palabras claves: Arte de África, arte de Oceanía, vanguardia europea, mercado de subastas, estrategias de marketing, catálogos de venta, cross-collectors, Christie's, Sotheby's

Keywords: African art, Oceanic art, European avant-garde, auction market, marketing strategies, auction catalogues, cross-collectors, Christie's, Sotheby's

\section{AUTHOR}

\section{TAMARA SCHILD}

Laboratoire d'anthropologie sociale, École des Hautes Études en Sciences Sociales, Université de recherche PSL

tamara.schild@ehess.fr 